\title{
PSYCHIC WHOLENESS \\ IN THE CONTEXT OF ANNA TERRUWE AND CONRAD BAARS' THEORY OF REPRESSIVE NEUROSES
}

ANNA LIPSKA *

Institute of Psychology

\section{ABSTRACT}

In the 1970s, two Dutch psychiatrists, Anna DIFFERENTIATION OF SELF

Terruwe and Conrad Baars, developed an innovative theory and therapy of repressive neuroses. Their theory was founded on the philosophical anthropology of Saint Thomas Aquinas. This approach to neuroses stemmed from the observation that contemporary psychiatry and psychology lacked philosophical underpinnings and that sciences thus formed were unable to help people. The key concept in the theory of repressive neuroses is psychic wholeness - the unity of the senses, the intellect, and will under the natural guidance of the last two of these. Stressing the great importance of this wholeness of human sensory and intellectual faculties for mental health has its consequences in the approach to and treatment of repressive neuroses. Every neurotic disorder is a kind of disintegration (repression of emotions and lack of intellectual control); therefore, the therapeutic process is supposed to effect a reintegration of distinct human faculties. The article presents the concept of psychic wholeness in the context of the theory of repressive neuroses, with special focus on Aquinas' anthropology as the philosophical basis for this theory. Bowen's concept of differentiation of self is also discussed and its similarities to psychic wholeness are pointed out.

56 INTRODUCTION

56 THE STRUCTURE AND FUNCTIONS OF SENSORY AND INTELLECTUAL FACULTIES

58 TERRUWE AND BAARS VS. ST THOMAS AQUINAS: DIFFERENCES

58 THE THEORY OF REPRESSIVE NEUROSES

59 THE TYPOLOGY OF REPRESSIVE NEUROSES

60 PSYCHIC WHOLENESS

63 RELATED PERSPECTIVES

64 CONCLUSION

65 REFERENCES 


\section{INTRODUCTION}

ince the times when psychology emerged from philosophy, the two disciplines have remained closely or distantly related, depending on the issues addressed. Over the centuries, numerous thinkers have tried to define the place of psychology in relation to philosophy (Beneke, 1923/2017; Feigl, 1959; Gonzalez, 2018; Maryniarczyk, 1995; Noras, 2017; Twardowski, 1913). On the other hand, many psychological conceptions directly draw on various philosophical theories (e.g., Frankl, 2010; Gałdowa, 2000; Wundt, 1913). It also sometimes happens that, to defend the autonomy of their discipline or its object of study, psychologists attempt to dissociate themselves from its philosophical origins. An example of such an approach was the emergence of behaviorism (Watson, 1990). It seems, however, that psychology cannot be separated from philosophy, and traces of the latter can be found even in the description of specific psychological issues and in therapeutic practice itself.

A not particularly well-known but immensely interesting example of this kind of marriage of psychology and philosophy is the perspective on repressive neuroses proposed by two Dutch psychiatrists, Terruwe and Baars (1989), dating back to the 1970s and based on Saint Thomas Aquinas' theory of human emotions (ST I-II, q. 22-48). The key concept in this theory is psychic wholeness. It should be noted that the authors largely relied on Brennan's (1941) Thomistic Psychology rather than directly on the works of Aquinas. This makes their philosophical anthropology a kind of interpretation of Aquinas' anthropology rather than simple endorsement of his ideas.

\section{THE STRUCTURE AND FUNCTIONS OF SENSORY AND INTELLECTUAL FACULTIES}

Terruwe and Baars (1989) observed that the psychiatry and psychology of their times lacked philosophical underpinnings ${ }^{1}$ and that science thus formed was unable to help people in an appropriate way. The authors stressed that knowledge of the "structure" of the human psyche was indispensable for the understanding of emotional disorders. The first important element of the human psyche that they mentioned was drives: the natural drive to obtain a good; this good is, firstly, the will to live (the drive for self-preservation), and secondly-the transmission of life (the procreative drive). Human nature, however, is not limited to the level of these drives but transcends it through the acquired sensory and intellectual knowledge. Thanks to this knowledge, basic drives can develop into a broad array of sensory and intellectual inclinations that lead a person to improve his or her existence. Next, the authors described three dimensions of the human psyche: sub-sensory (basic processes and activities aimed at the preservation of life), sensory (allowing the person to transcend themselves and comprising: sensory cognition, sensory appetite, and movement), and intellectual (making it possible to transcend the senses).

Human senses concern both cognition and appetites (i.e., desire). Cognition / knowledge is related to sensory cognitive powers: external powers (sight, hearing, smell, taste, touch) and internal ones (the central unifying sense responsible for the integration of knowledge

1 Similar conclusions have been reached by contemporary scholars (Morawski, 2019; Woźniczka, 2008). 
coming from various external senses, imagination, memory, and utility judgment / the power of judgment). All these powers are strictly linked to the intellect, which uses and enhances them. As far as sensory appetites are concerned, the authors (Terruwe \& Baars, 1989) have two types of appetites in mind and, consequently, two types of emotional responses or feelings. The first one is the pleasure appetite (the concupiscible power) - one feels attracted or repulsed depending on whether something is good or evil. Due to the multiplicity and diversity of objects, the pleasure appetite is associated with many different emotions: The first of these is love (pleasure) or its opposite, displeasure, followed by desire or aversion and by joy or sorrow ${ }^{2}$. The second appetite is the utility appetite (the irascible power), which draws a person's attention to obstacles and threats. It operates by trying to clear the way forward for a person who already desires an object and wants to obtain it. The emotions that accompany this appetite are hope and courage on the one hand and despair and fear on the other. Terruwe and Baars (1989) reduce these four emotions to two attitudes, jointly referring to hope and courage as energy and to despair and fear simply as fear. There is also the very important emotion of anger, which arises when one is striving but failing.

What Terruwe and Baars $(1989,2004)$ consider very important is the interrelatedness of the two appetites; it is a healthy relationship between them that "healthy" emotional life is based on. In emotional life, emphasis is placed on the pleasure appetite. Otherwise emotional life falls into disharmony, which has a detrimental effect on the person's entire mental life. When the utility appetite dominates over the pleasure appetite, the outcome is an extremely materialistic attitude that limits emotional life and leads to emotional problems.

As regards the intellectual dimension, the authors (Terruwe \& Baars, 1989) believe it is what makes a human being human. They believe that what is the most significant for human mental life is its sensory dimension, but they do not ignore the great significance of intellectual faculties (the intellect and will). The intellect (intellectual cognitive power) is a spiritual, immaterial power and enables a person to get to know what is universal by means of abstract concepts. This does not mean that the intellect is totally independent of the senses, in accordance with the principle that "nothing exists in the intellect that did not exist first in the senses" (Nibil est in intellectu quod non sit prius in sensu). Besides, the functioning of the intellect is dependent on the condition of the body (e.g., the better developed the brain, the greater the knowledge). In the case of the intellect, just like in the case of the senses, one has an intellectual desire that induces a longing to get to know the immaterial—namely, will.

From the practical point of view, what seems to be the most significant for a person is the relations between the constructs described. Harmony should reign in the relationship that links the intellect and will with sensory appetites. Sensory appetites should be subordinate to the intellect and to will, due to the superiority of the last two. As Andrzejuk (2020) points out:

Tomasz z Akwinu nie tylko postuluje możliwość rozumnego uregulowania naszej uczuciowości, ale uważa, że jest to naturalny stan naszych uczuć. Sądzi bowiem, że władze „niższe”, czyli zmysły, są w naturalny sposób podporządkowane władzom „wyższym”, czyli intelektualnym, i wobec tego głosi (bulwersującą dla niektórych) tezę, że uczucia „chcą” słuchać intelektu i woli, że jest to ich naturalny stan, wynikający z bytowej struktury człowieka.

[Aquinas not only postulates the possibility of intellectually regulating human emotionality but in fact considers this to be the natural state of human emotions. This is because he believes that the "lower" faculties (the senses) are naturally subordinate to the "higher" faculties (namely, to intellectual ones); consequently, he advances the thesis (which some regard as

\footnotetext{
2 For more on the differences in the names of emotions in Polish translations, see Andrzejuk, 1991, 2006.
} 
outrageous) that emotions "want" to listen to the intellect and will and that this is their natural state, following from the ontic structure of man.] (p. 56)

If humans were perfect, there would always be this kind of order between the senses and intellectual faculties. But because they are not, sensory appetites very often break loose from will or reason. The sensory appetite acting against the intellectual powers is a defect in mental life, leading to anxiety, irritation, guilt, and a sense of imperfection. The situation of such discomfort cannot continue for too long. Sooner or later, the sensory appetite that defied reason will submit to it. The authors (Terruwe $\&$ Baars, 1989) point out that it is easier to restore harmony between emotions and intellectual powers because this means returning to the natural guidance of reason and will. In relations between sensory appetites themselves there is no natural guidance of any of them, which is why conflicts between them are more dangerous to mental health.

\section{TERRUWE AND BAARS VS. ST THOMAS AQUINAS: DIFFERENCES ${ }^{3}$}

There are a few differences between Terruwe and Baars' (1989) interpretation of Aquinas' anthropology and his original theory set out in Summa theologiae (ST I-II, q. 22-48). For instance, in Aquinas there are no drives-there are three types of appetite: natural (appetitus naturalis), sensory (appetitus sensitivus), and intellectual (appetitus intellectivus). Likewise, the three dimensions of man in Terruwe and Baars appear to correspond to the three powers substantiated in the human soul (vegetative, sensory, and intellectual) as presented in Aquinas. Baars and Terruwe speak of sensory appetites, while Aquinas speaks of appetitive powers. It seems, however, that all these differences are merely terminological and connected with the striving to make the information presented accessible to psychologists. A somewhat greater departure from the original can be found in the discussion of the intellect and will; for example, the Dutch authors do not distinguish between the two types of intellect (active and potential) and do not address the issue of relations between the intellect and will. Aquinas' theory of the intellect and intellectual cognition is very elaborate (Zembrzuski, 2019), whereas Terruwe and Baars, by contrast, devoted little space to it. It seems that the authors either misunderstood Aquinas or deliberately simplified his extensive and rather difficult theory. They were interested in the anthropological basis, but-as they stressed many times in their publications (Terruwe \& Baars, 1989, 2004) - they also wanted their theory and published books to be comprehensible not only to scholars and physicians but also to ordinary people (potential patients).

\section{THE THEORY OF REPRESSIVE NEUROSES}

The Latin verb reprimo, reprimere means "to repel," "to restrict," or "to repress" (Kumaniecki, 1986). In contemporary psychology, repression is known above all as one of the basic defense mechanisms. It is one of the essential terms in psychoanalysis, and it is to psychoanalysis that it owes its popularity (Laplanche \& Pontalis, 1996). According to Terruwe and Baars (1989), the essence of repressive neurosis lies in the fact that some emotions emerging in the psyche have been repressed by an opposing force but not destroyed by it-merely pushed back, which means they continue to influence the person's life, but not in a pathological way.

3 For a detailed comparison of the two conceptions, see Andrzejuk, 2006; Kozłowska, 2008. 
Regarding this issue, the authors acknowledge the contribution of Freud (1917/2001), who drew attention to neuroses resulting from the repression of emotions (though he did not call them repressive neuroses), but they disagree with him about the repressive force being the superego (Welter, 2019). They believe that repressive conflict is one between emotions, not between an emotion and the superego (Terruwe \& Baars, 1989). This kind of conflict, which is the essence of repression, involves two contrary emotions about the same object: One is attracted to the object and at the same time repulsed by it. As there are three types of appetites in man (two sensory appetites and a spiritual one above them-namely, will), conflicts may arise between a sensory appetite and will or between sensory appetites themselves. The former type of conflict tends not to lead to repression, as the senses, by nature subordinate to the intellect that guides human will, eventually submit to it (Andrzejuk, 2006; Terruwe \& Baars, 1989). This happens, for example, when one overcomes the fear of surgery that is necessary for one's health. Repression usually arises between the utility appetite and the pleasure appetite, because neither of them is by nature subordinate to the other. An example can be a situation in which the utility judgment is misinformed and "forbids" the person to desire a particular thing, judging it to be harmful and causing fear to arise. This happens, for instance, when one feels sexual desire and at the same time fears the object of that desire. Because everything happens at the emotional level, the intellect in unable to judge the conflict and it is the stronger emotion (usually fear) that prevails. The weaker emotion is driven back but does not cease to operate and causes constant tension. The intellect and will are unable to restore balance because the repressing emotion precedes them (i.e., stands between the intellect and the repressed emotion). The degree of awareness of the repressed emotion varies and depends on the intensity of repression. In the light of the findings reported by contemporary psychologists of emotions (Gasiul, 2007; Łosiak, 2010), one might disagree with the authors' opinion that in a conflict of two emotions it is the stronger one that prevails; it may actually be the case that the emotion with greater repressive force will be the one to which the person merely attributes such significance, or the one that lasts longer.

Terruwe and Baars (1989) distinguish two types of repression: when the pleasure appetite is repressed by the utility appetite and when the reverse is the case. The former type of repression is much more frequent, and it is this one that the authors focus on (Terruwe \& Baars, 1989). Due to the emotions that accompany the utility appetite, reduced by the authors to two attitudes: courage and fear, repression can be energy-based or fear-based (energy and fear being the repressing emotions in such cases). As regards the emotions that can be repressed, the authors stress that the more frequent case is the repression of emotions associated with the pleasure appetite (love / displeasure, desire / dislike, joy / sorrow), and among them-those associated with the sensory good are repressed more often than those associated with evil. Among the emotions linked with the pleasure appetite, fearbased or energy-based repression of anger is the most common. The authors add that it is very important what objects the repressed emotions are associated with; the most frequent cases are repressions of the sexual drive, there are those that concern eating and drinking (e.g., anorexia), and there are also repressions related to the basic human desires, mainly the desire for self-realization.

\section{THE TYPOLOGY OF REPRESSIVE NEUROSES}

Terruwe and Baars (1989) divide neuroses into two main groups: hysterical neuroses and obsessive-compulsive neuroses. The criterion for this division is the dual effect of the repressive process: in the former case, the clinical picture is determined above all by the repressed 
emotion, while in the latter case it is determined mainly by the repressing emotion. In hysterical neuroses, signs of the repressed emotion, only partly inhibited by the repressing emotion, manifest themselves freely (because the repressing emotion has eliminated the control exercised by the intellect) and often in a pathological manner; when the repressing emotion is very strong, the repressed one has to find another channel of expression, very often through conversion (e.g., vomiting, states of semi-consciousness, trances, pareses, or paralyses). In obsessive-compulsive neuroses, by contrast, the repressed emotion is active but totally dependent on the repressing emotion; because there are two emotions that may be involved, two kinds of neuroses are possible. The first one is fear neurosis; fear is acquired and determines a person's entire functioning; it manifests itself in both somatic and psychological symptoms (all irrational fearful attitudes). The second one is energy neurosis; all emotions are dominated by courage and boldness, so the person appears to be emotionally stable and feels that his or her actions are effective; problems appear in relations other than those based on the repressing emotion; the person lives in a state of continual self-imposed guardedness and constant tension; physical exhaustion is frequent. There is also fear neurosis camouflaged by energy; it stems from deep-seated fear, but because it is usually found in "strong-willed" individuals, fear is at variance with their nature and repression initiated by fear is maintained by energy, which takes over the functions of the repressing factor.

Relating the above typology to contemporary clinical psychology or psychiatry, one will notice, above all, that today the term "neurosis" is being abandoned. The current diagnostic systems (DSM-5, ICD-11) practically do not use this term any more-it has largely been replaced with the category of anxiety disorders. It is still used in clinical practice, thoughusually to describe anxiety symptoms and the behaviors that accompany them, or with reference to a wide range of mental disorders other than psychotic. But classifications are built mainly based on symptoms. Accordingly, the symptoms that would be characteristic of repressive neurosis can be found under anxiety disorders, obsessive-compulsive disorders, or dissociative disorders (Gałecki et al., 2018; World Health Organization, 2019). There is no detailed information about the causes there, however. The psychoanalytic perspective on neurosis includes its cause. As mentioned before, this cause is the conflict between the instinctual id and the superego incapable of tolerating its needs (between needs and duties, between aspirations and actual possibilities, or between desires and ethical norms). If the ego is unable to reconcile the drives of the id and the aims of the superego, this leads to the emergence of symptoms associated with the superego repressing the energy of the id-first of all, anxiety (Freud, 1917/2001, 2002). According to Terruwe and Baars (1989), the cause of neuroses is different. They agree about conflict and repression, but they stress the role of emotions as such, the conflicts between them, and the repression of one emotion by another with the guidance of the intellect inactive. This perspective is rooted precisely in St Thomas Aquinas' theory.

\section{PSYCHIC WHOLENESS}

In order to prevent the neuroses described above, it is necessary to effect a person's psychic wholeness. Optimally, this takes place in the course of development, education, and experience. The healthy development of emotions is absolutely indispensable for the harmonious growth of all human mental life. Terruwe and Baars (1989) stress that what is particularly 
important is the proper development of the emotions associated with the pleasure appetite. They write:

Whatever constitutes an objective good for man must also be experienced and felt by him subjectively as good. Human beings are heir to an endless number of goods, due to the fact that their sensory cognitive life, ennobled as it is by the intellect, shares in the intellect's universality. These goods, however, must be made available to them to the full extent of their innate powers, if they are to mature fully and enjoy the richness of their human nature. Evidently, the richer and more sensitive the innate disposition of the emotional life, the greater will be its need to develop in its entirety. (p. 217)

The authors also point out that this natural development of emotions requires rational control over the emotional life taking shape. In the early stages of development, this control should be exercised by parents and educators. With time, reason and will develop sufficiently for adolescent children to learn to control their emotions. What poses a threat to development is both a situation in which the child grows without rational control over his or her emotional life and, consequently, does not achieve full wholeness and sensitivity to the guidance of reason, and a situation in which the child does not develop his or her emotional life (e.g., due to excessive demands, due to lack of play and entertainment, which make it possible to develop the pleasure appetite, or due to ignoring the emotions of anxiety and anger, which make it possible to develop an adequate utility appetite).

Wholeness is a union of intellectual and sensory powers, with the former controlling the latter, preventing conflicts or solving them in favor of rational actions (and thus in favor of natural and therefore healthy functioning). Reason can influence the sensory cognitive powers-namely, imagination and the power of judgment, and thereby suggest and correct the emerging ideas and intentions. For instance, it makes sure that absurd ideas do not emerge (e.g., a mouse is a great and terrible evil threatening our life). It is also possible for reason to manipulate the intentions arising; for example, in a gourmand who has developed diabetes the idea of a sweet cake is transformed in such a way that it becomes an object of aversion rather than desire. Will, by contrast, does not have influence on sensory cognition but can directly control emotions and may simply not let the gourmand reach for a cake. He will continue to strongly feel like eating the cake, but will not eat it in fear of the consequences (Andrzejuk, 2020). Aquinas discusses the ways of controlling emotions in more detail in his Treatise on Human Acts (ST I-II, q. 1-21). The control of emotions by will in his anthropology comes down to two moral virtues: moderation and fortitude (ST I-II, q. 49-70).

If, for some reason, the child has not been provided with a "wholesome family union" (Terruwe \& Baars, 1989, p. 230) and conditions for optimal emotional development, and if this resulted in repressive conflict and neurosis, what remains to be done is to restore psychic wholeness through the therapeutic process. Every therapy, regardless of the type of neurosis, has one central aim: to restore psychic wholeness, to reintegrate what has been torn by conflict in the disorder, and to put the conflicting emotions under the control of reason again. In other words, it can be said that therapy is supposed to allow the patient to restore the rational order. This means therapy usually consists in molding the patient's intellect and thereby restoring the natural control of the intellect over emotions. What is also characteristic is the humanistic approach to the patient. The physician / therapist is supposed to accompany and help, but not to impose anything, not to cause difficult situations, and not to provoke; he or she is rather supposed to wait for the spontaneous development of the therapy and to follow the patient, showing patience and building an atmosphere of security and trust.

As regards specific recommendations concerning particular types of neuroses, in the case of hysterical neurosis the most important thing is to bring the repressed emotion into 
consciousness and then to teach the patient to respond rationally to emotions and to cope with them. In the case of obsessive-compulsive neuroses, where self-consciousness is much higher, therapy is aimed at reducing the intensity of the repressing emotion (soothing the fear or inhibiting excessive energy). In fear neurosis it is highly important to make the patient trust the therapist; the patient must learn to trust, because trust is the key antidote to fear. The treatment of energy neurosis is very difficult because it requires convincing the patient to change their views and philosophy of life and to slow down-and the patient's strong personality makes it difficult to convince them to do anything (Terruwe \& Baars, 1989, 2004).

In practice, the therapy recommended by the authors and the one used nowadays (Feltham \& Horton, 2013; Grzesiuk, 2006) are similar. For instance, in psychodynamic therapy (Gabbard, 2012) it is important in the treatment of neurotic or anxiety disorders to gain access to the emotions and experiences that caused the fear and led to the perception of some emotion or need as threatening. Only contact with the forgotten difficult material leads to the reappraisal and processing of these difficult emotions, which makes change possible. In cognitive-behavioral therapy of anxiety disorders attention is devoted to reducing the symptoms perceived by the patient, discovering the mechanisms that lead to the emergence of disorders, and changing the disadvantageous way of thinking (Clark \& Beck, 2018). In practice, changing the way of thinking and work on beliefs seem to resemble the molding of the intellect. An unquestionable difference is the terminology used and the fact that in a number of psychotherapeutic approaches emphasis is not placed-as it is in Terruwe and Baars (1989) — on restoring the control of reason over emotions as the central aim of neurosis therapy. This control is rooted in the intellectualism of St Thomas Aquinas, who-for a philosopher-devoted much space in his anthropology to emotions but attributed primacy to the intellect. In contemporary psychology there are ongoing disputes about the relationship between emotions and cognition and about the primacy of one of them (Gasiul, 2007; Łosiak, 2010), and therefore the very aim of therapy may seem debatable.

It should be added that Terruwe and Baars (2004) also developed a theory and, above all, therapeutic recommendations regarding a disorder they called deprivation neurosis (or, alternatively, emotional deprivation disorder). The symptoms of this neurosis were not new, but no one before the Dutch authors had distinguished them from neuroses in general as described by Freud. They did it based on many years of research, observation, and medical practice, which showed that there was a type of neurosis that was not cured by repression-oriented therapy aimed at restoring psychic wholeness. Emotional deprivation disorder consists in an impairment of emotional life caused by repression. It was for problems such as this that they developed affirmative therapy (see more: Affirmation Therapy, n.d.).

In His Image Counseling Center, and In His Image Psychiatry (within The Baars Institute) are located in the United States (Irving, Texas). They present their mission and work as follows:

We offer individual, marital and family therapy from a systemic perspective. Our theoretical model is based on the Christian anthropology of St. Thomas Aquinas, which provides us with an understanding of the nature of the human person.

With this foundation, using the Baars-Terruwe Method, we work to restore wholeness to persons who present with a variety of issues, including Emotional Deprivation Disorder and the unaffirmed state, obsessive-compulsive disorder, depression, anxiety, phobias, and scrupulosity. (In His Image Christian Counseling, n.d.) 


\title{
RELATED PERSPECTIVES
}

Certain probably unintended echoes of the perspective on human maturity proposed by Terruwe and Baars (1989) and, consequently, distant links with St Thomas Aquinas's theory (ST I-II, q. 22-48) can also be found in Bowen's $(1976,1978)$ concept of differentiation of self. In his model of family functioning, Bowen $(1976,1978)$ thoroughly discussed the phenomenon differentiation, relating it both to families (well and poorly differentiated families) and to individuals (well and poorly differentiated). In the latter context, differentiation of self is a personality variable of key importance for development and for the subsequent attainment of mental health. Plopa (2008) writes:

\begin{abstract}
Dotyczy zdolności członków rodziny do wyrażania swojej własnej indywidualności oraz autonomicznego działania przy jednoczesnym zachowaniu więzi z innymi. Taka zdolność do rozwoju i działania w sposób samoróżnicujący umożliwia kształtowanie kompetencji i motywacji na rzecz przygotowania do dojrzałego pełnienia różnych ról i obowiązków w dorosłym życiu.

[It refers to family members' ability to express their individuality and to act autonomously while at the same time maintaining a bond with the others. This kind of ability to develop and act in a self-differentiating way makes it possible to develop skills and motivations preparing a person for the serious roles and duties of adult life.] (pp. 70-71)
\end{abstract}

Well-differentiated families create a particular kind of context for the functioning of individuals - the kind of context that is conducive to their development, allowing them to differentiate themselves and to act according to their conscience. The individuals who develop in this way are able to organize their experience into a coherent and meaningful whole. They can smoothly and flexibly manage their emotions and have a sense of being in control of the course of their life. According to Bowen (1978), differentiation of self determines the degree to which a person is in a state of balanced emotional and intellectual functioning (the intrapsychic level) and in a state of relational intimacy and autonomy (the interpersonal level). At the intrapsychic level, it means the ability to distinguish thoughts from feelings and to choose between being guided by the intellect or by one's emotions (depending on the circumstances). By contrast, poorly differentiated individuals are frequently unable to maintain balance between emotions and the intellect and show a tendency to act and make decisions under the influence of emotions (without involving the intellect, even when this would be necessary). At the interpersonal level, differentiation of self refers to the ability to experience intimacy while maintaining independence from others and makes it possible to maintain flexible boundaries-namely, emotional intimacy and physical relationship with another person with no fear of merging (Skowron \& Friedlander, 1998). Bowen $(1976,1978)$ stresses that differentiation of self should be distinguished from individuation and autonomy. Although these concepts are similar in some respects, they are not synonymous. Individuation and autonomy are associated with achieving independence and a unique sense of identity, whereas differentiation of self is the ability to think independently and to build self-consistency in the context of meaningful relationships with others (Skowron \& Friedlander, 1998).

Bowen (1978) writes about psychological maturity attained by well-differentiated individuals - namely, by those who are in a state of balance between emotional and intellectual functioning and between relational intimacy and autonomy. He does not use the term wholeness, just like Aquinas did not use the term maturity. Certain similarity can be noticed, however. In both theories the condition of normal functioning, of coping with difficulties 
(crises), and, finally, of mental health is, as Bowen (1978) writes, the cooperation of the intellect and emotions - under the natural guidance of the former, as Aquinas would add (ST I-II, q. 22-48). Moreover, both the Dutch authors and Bowen stress the significance of childhood and adolescence and the context of normal family functioning as crucial to the development of abilities that set the foundations for psychic wholeness or maturity.

\section{CONCLUSION}

To sum up, Terruwe and Baars based their conception of repressive neuroses on Aquinas' theory of the human psyche and human emotions. Their adaptation differs from the original mainly in terminology; the authors of Psychic Wholeness try to modernize Aquinas' language and facilitate its reception for psychologists. Moreover, they shift the emphasis from intellectual powers, which seem to be the most important for Aquinas, to the senses and emotions, which are the most significant for the Dutch authors because they are a source of internal conflicts and, consequently, repressive neuroses. But the differences do not change what seems to be central both for St Thomas and for Terruwe and Baars, and to some extent also for Bowen-namely, psychic wholeness integrating emotions, the intellect, and will under the natural guidance of the last two of these. It should be stressed that Aquinas' conception is exceptional (in philosophical anthropology) in that it takes note of human feelings. Aquinas considers emotions to be a natural component of the human psyche, one that a person must not ignore but has to learn to live with, while Terruwe and Baars as well as Bowen underscore the significance of coherent functioning of emotions and the intellect, which is not frequent in psychology.

Despite its advantages (especially its interdisciplinary character and the assumptions of philosophical anthropology it starts out from), Terruwe and Baars' theory of repressive neuroses has not become widely known. It seems the authors themselves did not care about that - they focused on therapeutic practice, relations with patients, and passing on knowledge to students. The theory they developed and the assumptions they adopted were the point of departure they needed to offer therapeutic recommendations. The few other publications discussing their work, which were also practice-oriented and written with "ordinary people" battling against problems in mind, did not give it renown in the academic world of psychology.

The popularization of Terruwe and Baars' theory of repressive neuroses, the comparisons made, and the conclusions drawn may provide suggestions for further analyses. It is also worth trying to find links between this theory and others, thus attempting a greater generalization of the presented conception. This kind of research would contribute to the popularization of the presented approach and would serve as a point of departure for a holistic perspective on the human being-both at the level of theoretical integration and at the level of therapeutic practice. 


\section{REFERENCES}

Affirmation Therapy. (n.d.). Retrieved from: https://www.baarsinstitute.com/affirmation-therapy

Andrzejuk, A. (2006). Uczucia i sprawności. Warsaw, Poland: NAV0.

Andrzejuk, A. (2020). Tomasz z Akwinu jako psycholog. Warsaw, Poland: Naukowe Towarzystwo Tomistyczne.

Beneke, F. E. (2017). The Elements of Psychology on the Principles of Beneke. London, England: Forgotten Books.

Bowen, M. (1976). Theory in the Practice of Psychotherapy. In A. S. Gurman, D. P. Kniskern (Eds.), Handbook of Family Therapy (pp. 159-186). New York, NY: Brunner/Mazel.

Bowen, M. (1978). Family Therapy in Clinical Practice. New York, NY: Jason Aronson.

Brennan, R. E., O.P. (1941). Thomistic Psychology: A philosophic analysis of the nature of man. New York, NY: Macmillan.

Clark, D. A., \& Beck, A. T. (2018). Zaburzenia lękowe. Podręcznik z ćwiczeniami opartymi na terapii poznawczo-behawioralnej. Kraków, Poland: Wydawnictwo Uniwersytetu Jagiellońskiego.

[Description of the Baars Institute]. (n.d.). Retrieved from: https://baarsinstitute.com

Gałecki, P., Pilecki, M., Rymaszewska, J., Szulc, A., Sidorowicz, S. K., \& Wciórka, J. (Eds.). (2018). DSM-5. Kryteria diagnostyczne zaburzeń psychicznych. Wrockaw, Poland: Edra Urban \& Partner.

Feigl, H. (1959). Philosophical embarrassments of psychology. American Psychologist, 14, 115-128. https://doi.org/10.1037/h0047912

Feltham, C., \& Horton, I. (2013). Psychoterapia i poradnictwo. Gdańsk, Poland: GWP.

Frankl, V. (2010). Wola sensu. Założenia izastosowanie logoterapii. Warsaw, Poland: Czarna Owca.

Freud, Z. (2001). Wstęp do psychoanalizy (S. Kempnerówna, W. Zaniewicki, Trans.). Warsaw, Poland: De Agostini.

Freud, Z. (2002). Nieświadomość (M. Poręba, Trans.). In Z. Rosińska, Freud (s. 193-225). Warsaw, Poland: Wiedza Powszechna.

Gabbard, G. (2012). Długoterminowa psychoterapia psychodynamiczna. Wprowadzenie. Kraków, Poland: Wydawnictwo Uniwersytetu Jagiellońskiego.

Gałdowa, A. (2000). Powszechność i wyjątek. Rozwójosobowości człowieka dorosłego. Kraków, Poland: Wydawnictwo Uniwersytetu Jagiellońskiego. Gasiul, H. (2007). Teorie emocji i motywacji. Warsaw, Poland: Wydawnictwo UKSW.

Gonzalez, W. J. (Ed.). (2018). Philosophy of Psychology: Causality and Psychological Subject. New Reflections on James Woodward's Contribution. Berlin, Germany: De Gruyter.

Grzesiuk, L. (Ed.). (2006). Psychoterapia. Praktyka. Podręcznik akademicki. Warsaw, Poland: ENETEIA.

In His Image Christian Counseling. (n.d.). Rerieved from: https://www.ihicounseling.com

Kozłowska, A. (2008). Tomaszowa koncepcja psychiki i uczuć ludzkich jako podstawa teorii i terapii nerwic represyjnych w ujęciu A. Terruwe i C. Baarsa (Unpublished master's thesis). Instytut Filozofii UKSW. Warsaw, Poland.

Kumaniecki, K. (1986). Słownik łacińsko-polski. Warsaw, Poland: PWN.

Laplanche, J., \& Pontalis, J.-B. (1996). Stownik psychoanalizy (E. Modzelewska \& E. Wojciechowska, Trans.). Warsaw, Poland: WSiP.

Łosiak, W. (2010). Psychologia emocji. Warsaw, Poland: Wydawnictwa Akademickie i Profesjonalne.

Maryniarczyk, A. (1995). Filozoficzne „obrazy” człowieka a psychologia. Człowiek w Kulturze, 6-7, 77-99.

Morawski, J. (2019). The Replication Crisis: How Might Philosophy and Theory of Psychology be of Use? Journal of Theoretical and Philosophical Psychology, 39, 218-238. https://doi.org/10.1037/te00000129

Noras, A. J. (2017). Filozofia a psychologia. Próba charakterystyki problemu. Idea. Studia nad strukturq i rozwojem pojęć filozoficznych, 29(1), 5-23. https://doi.org/10.15290/idea.2017.29.1.01

Plopa, M. (2008). Psychologia rodziny. Kraków, Poland: Impuls.

Skowron, E. A., \& Friedlander, M. L. (1998). The Differentiation od Self Inventory: Development and initial validation. Journal of Counseling Psychology, 3, 235-246. https://doi.org/10.1037/0022-0167.45.3.235

Terruwe, A., \& Baars, C. (1989). Integracja psychiczna. 0 nerwicach i ich leczeniu (W. Unold, Trans.). Poznań, Poland: W drodze. (Original work published 1981/2016, Psychic wholeness and healing, 2nd ed.).

Terruwe, A., \& Baars, C. (2004). Integracja emocjonalna. Jak uwierzyć, że jesteś kochany i potrafisz kochać (M. Ciszewska, Trans.). Poznań, Poland: W drodze. (Original work published 2002, Healing the unaffirmed. Rev. ed.).

Tomasz z Akwinu (1963), Suma teologiczna I-II, Q. 6-21, Vol. 9, 0 uczynkach (F. W. Bednarski, Trans.). London, England: Veritas.

Tomasz z Akwinu (1967). Suma teologiczna I-II, q. 22-48, Vol. 10, Uczucia (J. Bardan, Trans.). London, England: Veritas.

Tomasz z Akwinu (1967). Suma teologiczna I-II, q. 49-70, Vol. 11, O sprawnościach (J. Bardan, Trans.). London, England: Veritas.

Twardowski, K. (1913). O psychologii: jej przedmiocie, zadaniach, metodzie, stosunku do innych nauk i o jej rozwoju. Warsaw, Poland: W. Łazarski. Watson, J. B. (1990). Behawioryzm oraz psychologia, jak widzi ja behawiorysta (J. Siuta, E. Klimas-Kuchtowa, Trans.). Warsaw, Poland: PWN. 